\title{
Code Switching as an Interactive Tool in ESL Classrooms
}

\author{
Mohamed El Mamoun Abdel Magid ${ }^{1} \&$ Abdelrahim Hamid Mugaddam $^{2}$ \\ ${ }^{1}$ King Abdul Aziz University, Jeddah Community College, Kingdom of Saudi Arabia \\ ${ }^{2}$ Associate professor (Linguistics), Director, Institute of African \& Asian Studies, University of Khartoum
}

Received: July 2, 2013

Accepted: August 11, 2013

Online Published: August 19, 2013

doi:10.5430/elr.v2n2p31

URL: http://dx.doi.org/10.5430/elr.v2n2p31

\begin{abstract}
This study addresses the role of code switching to students' L1 (Arabic) in their ESL classrooms and whether it expands interaction in these classrooms. The gap perceived in this area needs to be addressed towards the domains of sociolinguistics and applied linguistics in the ESL classrooms teaching environment. Henceforth, this study draws on data collected from basic, secondary and college ESL classrooms in the Sudan and Saudi Arabia. The study incorporates various data gathering procedures: audio-taped spoken data of some ESL classrooms, questionnaire and semi-structured interviews. The data has been analysed by descriptive statistics. The findings generally indicate that CS has been used extensively, purposefully and functionally as part and parcel of ESL classrooms' discourse. The overall findings suggest that, although the use of L1 has been criticized in the existing literature, yet it has been admitted by ESL teachers, showing that L1 use is unavoidable at basic, secondary and tertiary level in the Sudan and Saudi Arabia. In classrooms where both students and teachers share the same L1, there is a great tendency for using it in the fields of explaining meaning and difficult words, guiding interpretation, transmitting lesson content, illustrating grammatical rules, organizing ESL classrooms and praising and encouraging students. Thus, L1 has been found useful in expanding the interactions of ESL classrooms towards facilitating ESL learning process. The study also calls for sensitizing both teachers and students about the helpful uses of CS. Therefore, syllabi and methods of teaching ESL should incorporate CS in an occasional and judicious way.
\end{abstract}

Keywords: Code switching, Classroom interaction, Mother tongue use in EFL classes

\section{Introduction}

The term code switching (CS) for this study has been defined as "the alternation of two languages at the word, phrase, clause, and sentence levels." Valdes-Fallis (1976 in Abalhassan and Alshalawi, 2000:180-181), combined with the definition given by Richards's et al. (1992:58) that CS is" a change by speaker (or writer) from one language or language variety to another one. Code switching can take place in a conversation when one speaker uses one language and the other speaker answers in a different language. A person may start speaking one language and then change to another in the middle of the speech, or sometimes even in the middle of the sentence. CS has been for a long time a contentious issue debate. Some scholars spoke against attaching any role to L1 in L2 classrooms as time should be devoted completely to the L2 (Ellis, 2000; Krashen, 1985). Swan (1985) claims that L1 use in ESL classes would hamper ESL acquisition and goes far to favour direct translations than using students' L1. As such, a long tradition that switching to L1 in ESL, L2 and EFL, has been discouraged in these classrooms and even considered a taboo and a source of guilt and may be a hint of the weakness on the part of teachers (Auerbach 1993; Cook, 2001). However, a considerable amount of literature suggest that CS to L1 while teaching L2 may be productive or even necessary at some times (Atkinson, 1987; Auerbach, 1993; Canagarajah, 1995; Frankenberg-Garcia, 2000; Harmer, 2001; Murakami, 1999). Skuttnab-Kagnas (1994) goes far to argue that the L1 use in the educational process is a fundamental 'linguistic human right' of minority language groups'. Therefore, CS, from being viewed as a random phenomenon, it has come to be seen as a highly purposeful activity. As an area of special interest and investigation, CS in ESL classroom has also begun to receive growing attention around the world. As a common occurrence in ESL classrooms CS can be 'evidenced along the entire continuum of proficiency' (Brice 2000). Studies seem to suggest that teacher CS, whether in teacher-led classroom discourse or in teacher-student interaction, may be a sophisticated language use serving a variety of pedagogical purposes. Yet, some researchers called for occasional and judicious use of L1 in L2 classes to avoid over use of L1 (Auerbach, 1993; Hidayati, 2012; Weschler, 1997).

Modern teaching methodologies such as the Communicative Language Teaching (CLT) tend to overlook the use of L1 (Atkinson, 1997; Harmer, 1983 in Cole, 1998). The research area of CS is under-researched in the Arab/African 
world in general, and a virgin field in Sudan and Saudi Arabia, in particular. This shows a serious lack in this field as much time is devoted to grammatical competence. Hence research is badly needed in classroom interactions between the teacher and the students and the students themselves (Schweers, 1999; Nattinger and De Carrico, 1992). This study explores one of the least studied areas (if any) in ESL research in the Arabic environment. Investigating L1 use in ESL classrooms will hopefully contribute greatly to teacher education in order to improve teachers' effective implementation of the purposeful uses of $\mathrm{L} 1$ in teaching a foreign language.

\section{Literature review}

Literature review has been surveyed extensively and intensively from the 1970s to 2013. The review covered studies emanated from America, Western Europe, Asia, Africa, the Arab world and the Sudan. Many studies found that CS to students' L1 in the L2/ESL/EFL served hybrid useful functions that expand negotiation, understanding and hence interaction in the classrooms. CS in ESL classrooms might be considered an interactional resource that is used by both teachers and students in the process of reaching a native like competence in ESL/L2 (Ustunel and Seedhouse, 2005). Awad El Karim (2003) in Sudan found that, contrary to the general belief, CS is an actively positive and effective strategy in discourse. In L2 literature it is maintained that focus on meaning will help students to approximate L1 acquisition conditions and may even lead to similar success in the L2. In this case CS can help students use their L1 to elicit language meaning and encourage peer discussion to maximize L2 meaning comprehension (Brown, 2000; Larsen-Freeman, 2000; Pica 2000; Richards and Rodgers, 1986).

The process of guiding students to understand ESL is provided through 'negotiation' which in turn provides students with a context for second language in process. In ESL teaching processes 'collaborative dialogue' is mainly a problem-solving and knowledge-building process in which teachers and students interact frequently (Chaudron, 1988; Fasold, 1984; Lynch, 1996; Pica, 1992; Swain, 2000). Therefore, negotiation of meaning is the first step in the circle of interaction, which attracted a lot of attention.

Using CS has been found to smoothly transmit and communicate lesson content and to develop language skills such as solving problems and language analysis (Buckmaster, 2002; Cook, 2001; Cook, 2002; Cunningham, 2002; Dajani, 2002; Harbord, 1992, Harmer, 2001; Ur, 1996). Researchers (Atkinson, 1987; Deller, 2003; Harbord, 1992; Stern, 1992) have significantly shown that there is a possibility of transferring L1 knowledge to L2 learning as a strategy used by L2 students in different environments.

In L2 literature, there is an emphatic assertion that L2 students transfer the grammatical properties of their L1 into their L2 grammar (Towell and Hawkins, 1994). Researchers showed that students' L1 was used to explain errors, similarities and differences between the two language systems, and to present and discuss grammatical rules and spelling (Auerbach, 1993; Canagarajah, 1995; Gabrielatos, 2001; Stern, 1992).

Interaction in the classroom between teachers and students and among students is a distinguishing feature of CS (Auerbach, 1993; Canagarajah, 1995; Collingham 1988 in Auerbach, 1993; Piasecka, 1988 in Auerbach, 1993; Cook, 2001; Stern, 1992). CS involvement gives students the opportunity to engage in meaning-focused activities in order to comprehend and produce coherent utterances. Therefore, CS has been recommended as the basis for syllabus organization and a tool that enable teachers and students to regulate classroom interactions efficiently and systematically.

In line with the literature in the field CS, in this study has been searched under six categories: explaining meaning and new vocabulary, guiding interpretation, transmission of lesson content, illustrating grammatical rules, organizing classrooms and praising and encouraging students.

\section{Research questions}

The main question of this study is: how does CS in ESL classrooms facilitate the process of L2 learning to enrich interactions between teachers and students at EFL classes in the Sudan and Saudi Arabia? Further, the following specific questions represent the focus of this study:

1) What is the role of CS in increasing meaningful interactions in ESL teaching?

2) Should L1 use in ESL classrooms be allowed?

3) When should L1 use in ESL classrooms be allowed?

4) How frequently is CS used in ESL classrooms and for what purposes 


\section{Research design}

The study used three instruments in the process of data collection: Tape-recording, questionnaire and structured interviews. Recording was made in EFL classrooms at basic level, secondary schools and tertiary level. About 20 hours recording has been made covering the different types of the sample population. Questionnaires were administrated to teachers/lecturers in the field in order to explore their perceptions about using L1 in ESL classes. Semi-structured interviews were made with some of the practitioners to gain more insights into their practice regarding code/switching in EFL .

Data collection process had been undertaken within the period extending from Jan 2011 to February 2013. The process covered a sample population of teachers, students, and practitioners in Khartoum State, the Sudan, and the tertiary level, in Jeddah, Saudi Arabia. The focus of the study is entirely descriptive (Seliger and Shohamy, 1989). $150 \mathrm{EFL}$ teachers/lecturers have been examined about their use of L1 in their classes through administered questionnaires. The researchers randomly distributed about 200 copies; yet, received only 150 ones. The statements of this questionnaire tried to elicit teachers' views about the benefits of L1 in their EFL classrooms. The questions were operationalized by the previous research studies findings and contributions in the field. Eight ( 3 from the basic level; 3 from the secondary level and 2 from the tertiary level) of the teachers were observed and tape recorded consequently. The findings of the questionnaire will be discussed under specific categories. 15 of the teachers/lecturers were subjected to in-depth interviews where each one has been interviewed for about 45-60 minutes.

Data analysis were carried out by means of descriptive statistics and interpretive analysis to infer the L1 uses in EFL classes. This in turn, helps to identify various types of L1 uses in EFL teaching. Tables and figures have been utilized to show the number and percentage of respondents for each question. Some excerpts of interactions between teachers and students have been spelled out. Finally, some ideas expressed by the teachers were considered in the process of data analysis.

\section{Data analysis and results}

The findings of the questionnaire, tape-recording, interview and observation were discussed in tandem.

\section{Explaining meaning and new vocabulary}

Figure 1 below for question 1, showed that 133 of the respondents $(88.7 \%)$ reported that they strongly agreed or agreed to the statement that using L1 (Arabic) helps in explaining meanings of new words and items in EFL. However, only $17(11.3 \%)$ of them have been either undecided, strongly disagreed or agreed with the statement. The figure also shows that L1 has a role to play in explaining meanings of words, items and even concepts. This suggests that the teachers see CS is very useful in teaching English.

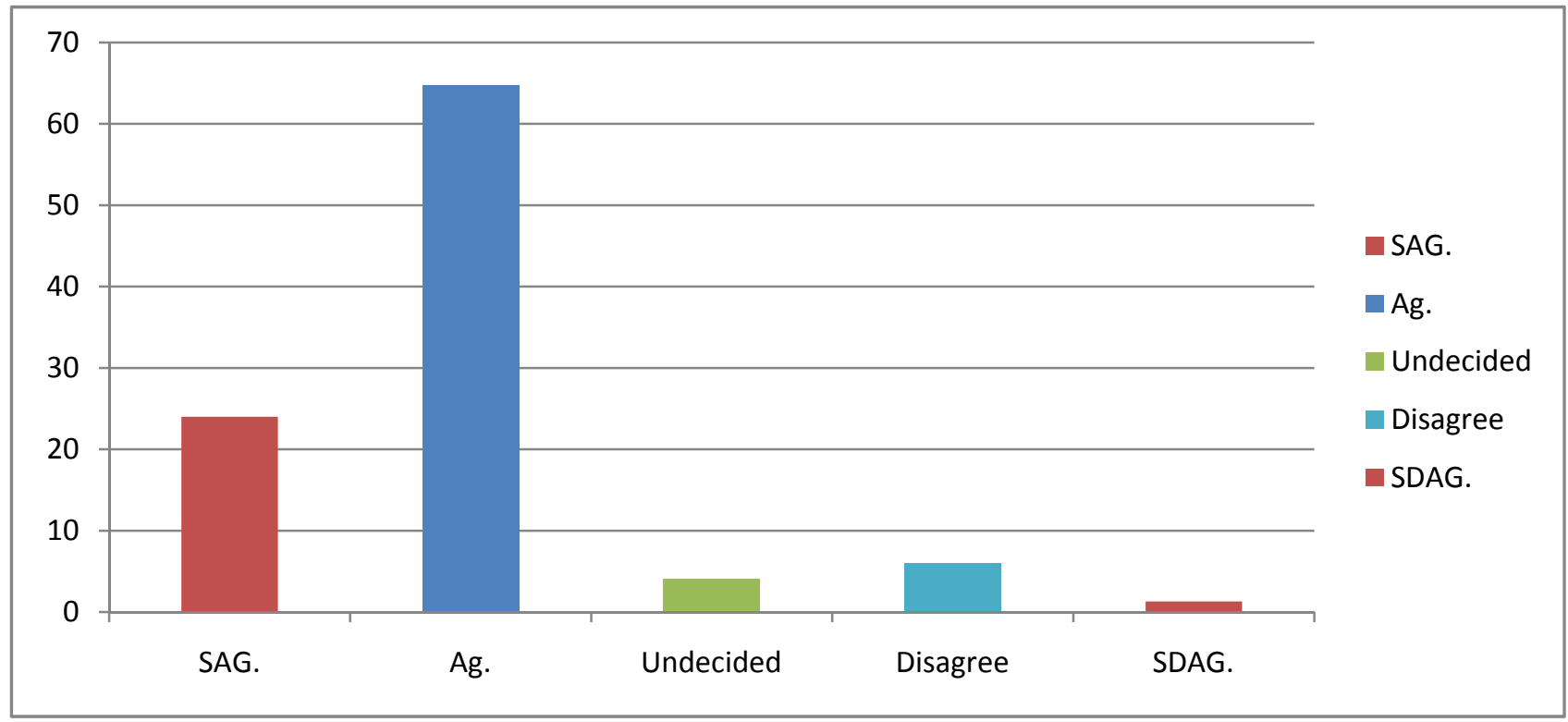

Figure 1. teachers view on using Arabic in EFL classes 
From observing classes it was clear that English and Arabic were used alternately. That is, sometimes the word is mentioned in English with a simultaneous Arabic translation such as 'Merchant (tajir). In this case the meaning in Arabic is mentioned first and followed by the equivalent in English, as in 'Di fikra (it is an idea)'; Sabr (patience). The following excerpts display the meaning of the new words in various kinds of CS. In the excerpts teachers start straightforwardly with Arabic words to explain the meaning of the new vocabulary, where most of them follow the sequence: L1-L2 (mentioning the equivalent Arabic words first and then the L2 words):

T: Mawqa'a ya'ni (location means)

T: Di fikra (it is an idea).

T: Mitain (when)

T: Muwatina (citizen)

T: Yala (OK)'suburb' ma'aha (matches with), 'outskirts'

The excerpts which explain words and hence help in comprehending the passages and paragraphs, have been supplemented by the teachers' stated beliefs from the interview, as they confessed to use L1 one in:

Comprehension and vocabulary.

.... Some vocabulary words that are difficult for students to understand the passage

L1 is used only if we feel that students are not understanding at all, and it is limited to vocabulary only.

Muir (2001) concluded that L1 has been used as a conscious strategy to negotiate meanings (thus, promoting classroom interaction) among other functions. Furthermore, the students have expressed positive attitudes towards L1 particularly in clarifying and introducing new words. Franklin (1991 in Cook, 2001:12) reported that 39\% of Scottish teachers used L1 for explaining meanings, while 30\% of them used L2, and the rest used L2 with some difficulty. This finding is supported by many studies such as Hosoda (2000), Swain and Lapkin (2000), Higareda et al. (2009), and Storch and Al Dosari (2010).

\section{Guiding interpretation}

Figure 2, below explores whether L1 helps in understanding different topics in EFL. 127 (84.7\%) of the respondents strongly agreed and agreed that student's L1 was helpful in comprehending ESL topics. However, 23 of the respondents $(15.3 \%)$ were rather undecided, disagreed or strongly disagreed.

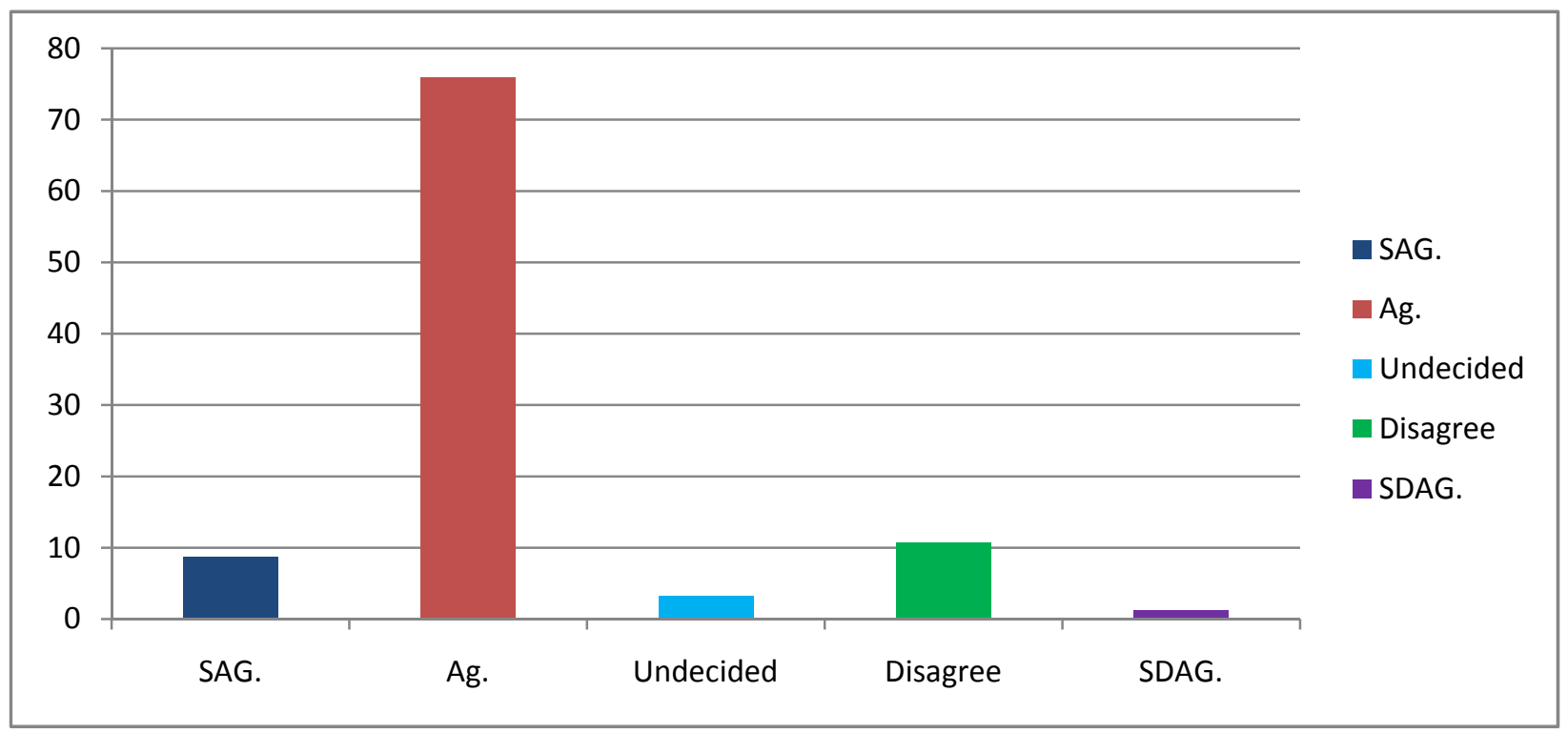

Figure 2. The role of L1 in understanding different topics in English classes

In the following sentence there has been a focus on a certain point to be explained by using one or two words:

T: Al Akheera di (yes, this last point). Tayib wa tani? (OK, any other one?). Ghabliha (before this).

Further, a word or two words in Arabic were used to guide students to focus on the interpretation of a certain passage, such as , a'aa, (yes), ya'ani (means) mudun (cities) or al hadar (urban way of life), mush kida? (is it not so?), - 
Tayib (OK, let's proceed), kiwais (OK), tayib nashuf (OK, let's see), mush kida (is it not so?), aha (OK), ... ma'naha (it means), as has been shown in the excerpt below:

T: $\boldsymbol{A}^{\prime} \boldsymbol{a} \boldsymbol{a}$, (yes), it is the main issue. You know rural, rural life, life in villages, $\boldsymbol{y a} \boldsymbol{a} \boldsymbol{a n i} \boldsymbol{a l}$ reef (it means rural way of life as in villages). Urban life means, life in towns or mudun (towns and cities) or al hadar (urban way of life), mush kida? (Is it not so?).

Another example in this regards is in the following extract:

S5: Dangerous.

T: Yes, dangerous, pronounce 'dangerous'. Ya'ni 'khateer', 'it means dangerous'

T: Ya'ni ghulna shinu? (what did we say?).

T: Yibgha eindu shinu? (then he will have what?) ... leisure time.

T: Ya'ni bil eidafa lai al dhawdha', hinak (in addition to the too much noise, there is) an unpleasant smell of diesel fumes ....

T: Tiftakru ha yikon eindu (do you think he has) a leisure time?

T: Bimshi wain? (where does he go?).

Some of the interviewed teachers supported this conclusion - students' L1 was used to guide the interpretation of phrases, sentences and paragraphs of the subject matter:

Using L1 in English classrooms gives most of the students an opportunity to understand well.

These findings show that L1 has served many pedagogical functions, including guiding interpretation (Adendorff, 1993; Harbord, 1992, Stern, 1992). This situation was in line with the finding of Prodromou's study (2001) in Greece. He found that both teachers and students at beginner and intermediate levels have overwhelmingly accepted the use of L1 (Greek) in their English classes for many functions including leading students to understand the contexts. This justifies why Cook 2001 and Atkinson *1987) called for the use of CS in English classes with the belief that it is a normal phenomenon through which students can help themselves and each other in their respective English classrooms to comprehend topics, contexts, and concepts. Further, Muir (2001) found that L1 has been used as a conscious strategy to negotiate meanings and hence promote classroom interaction.

\section{Transmission of lesson content}

Figure 3 below, showed that the majority of the respondents, $122(81.3 \%)$, perceived that translating words, phrases and sentences to comprehend the texts ensures that the content of the lesson has been understood. Yet, 28 of them $18.7 \%$ were undecided, strongly disagreed or disagreed with this statement.

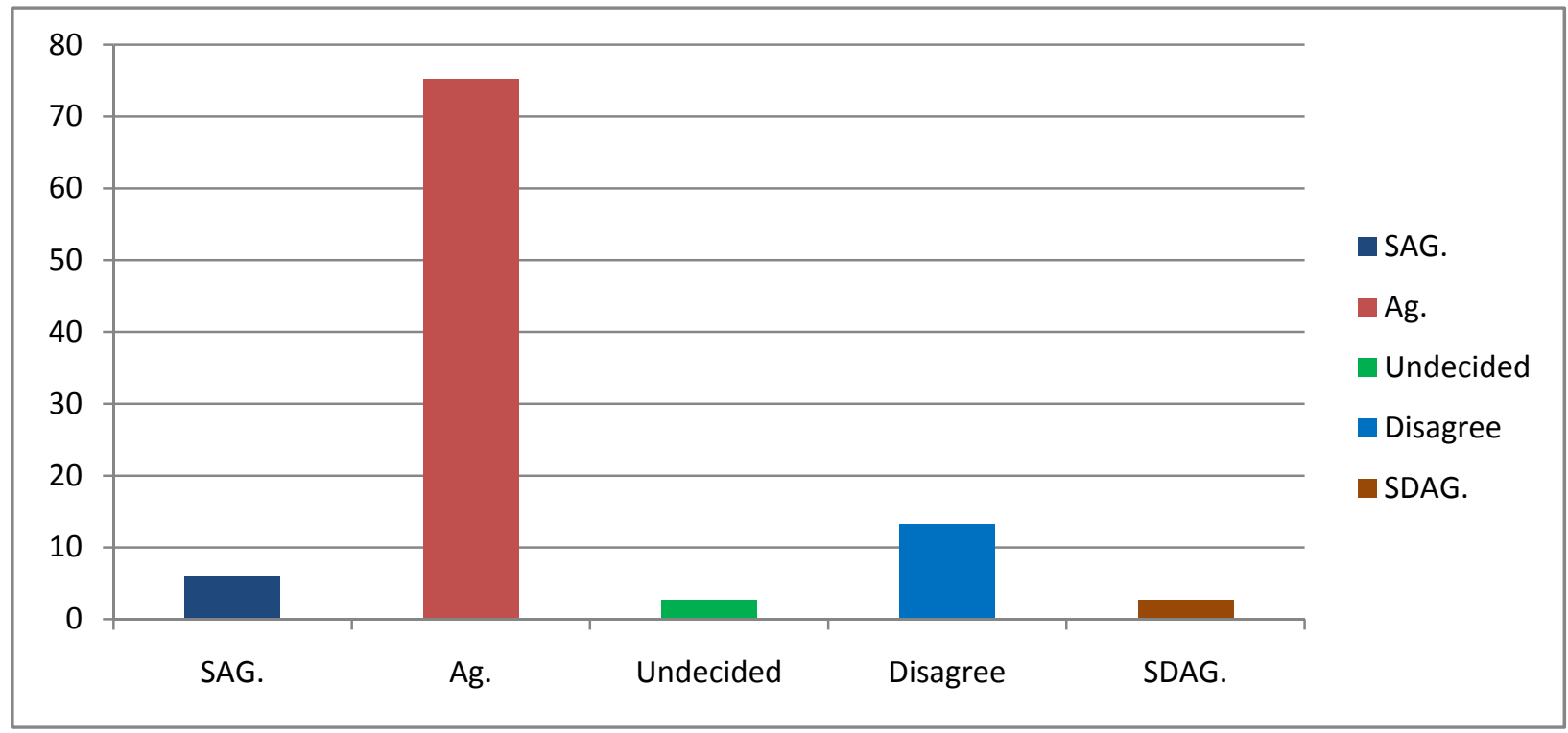

Figure 3. The role of translation in understanding English texts 
Some excerpts started in Arabic so as to help students understand the rest of the sentences or the paragraph. This might be considered a scaffolding strategy to comprehend the contextual meaning. In the following excerpts, the teacher started explaining in Arabic (L1) and then ended in English (L2). This suggests that the two languages can be used in a 'meaning continuum' not to provid separate meanings:

T: Da ghal laihum khaluna nantazir (this [Musa] said to them let's wait) for a big car

T: Di ma'naha hanantazir taweelan (that means we will wait for a long time).

T: Akeed ha yikun fi (surely there will be) 'much noise'.

In the first line of the above excerpt, Arabic has been used to explain the situational context where Musa has asked his colleagues to wait for a big car instead of their little stumbling car. In the second line, Arabic was used to explain the whole situation as they would stay for a long time waiting for the big car to come, so they should find another solution. The third line does not belong to the same context. However, it also started in Arabic to show that students should expect, in the industrial area, 'much noise'. The Arabic meaning and the English words were used in one sentence: started with Arabic (for explaining the meaning), and then English was used to continue in the contextual set of the passage. Similarly, one of the teachers stated that he used students' L1 when students failed to understand the subject matter and even comprehend the questions asked (... some words are not understood in English such as the adjectives: brave, beautiful; the nouns such as: love, fear, justice; adverbs: often, usually; verbs such as: dream ).

Similar studies concurred with the same results. Canagarajah's (1995) concluded that ESL teachers, while considering L1 inappropriate for ESL classrooms, unconsciously use it in a useful way such as translating language content. Adendorff (1993) reported that CS served important academic and social functions of different kinds in the classroom, including guiding academic activity, interpretation, and understanding social relations. Similar results have been reported by Abalhassan and Alshalawi (2000), Macaro (1997) and Jingxia (2010).

\section{Illustrating grammatical rules}

Figure 4 below shows teachers use of students' L1 to illustrate complex grammatical rules. 129 (86\%) of the respondents strongly agreed and agreed that they used students' L1 to explain difficult grammatical points and rules. However, 21 of them (14\%) of them reported that they were undecided, strongly disagreed or disagreed.

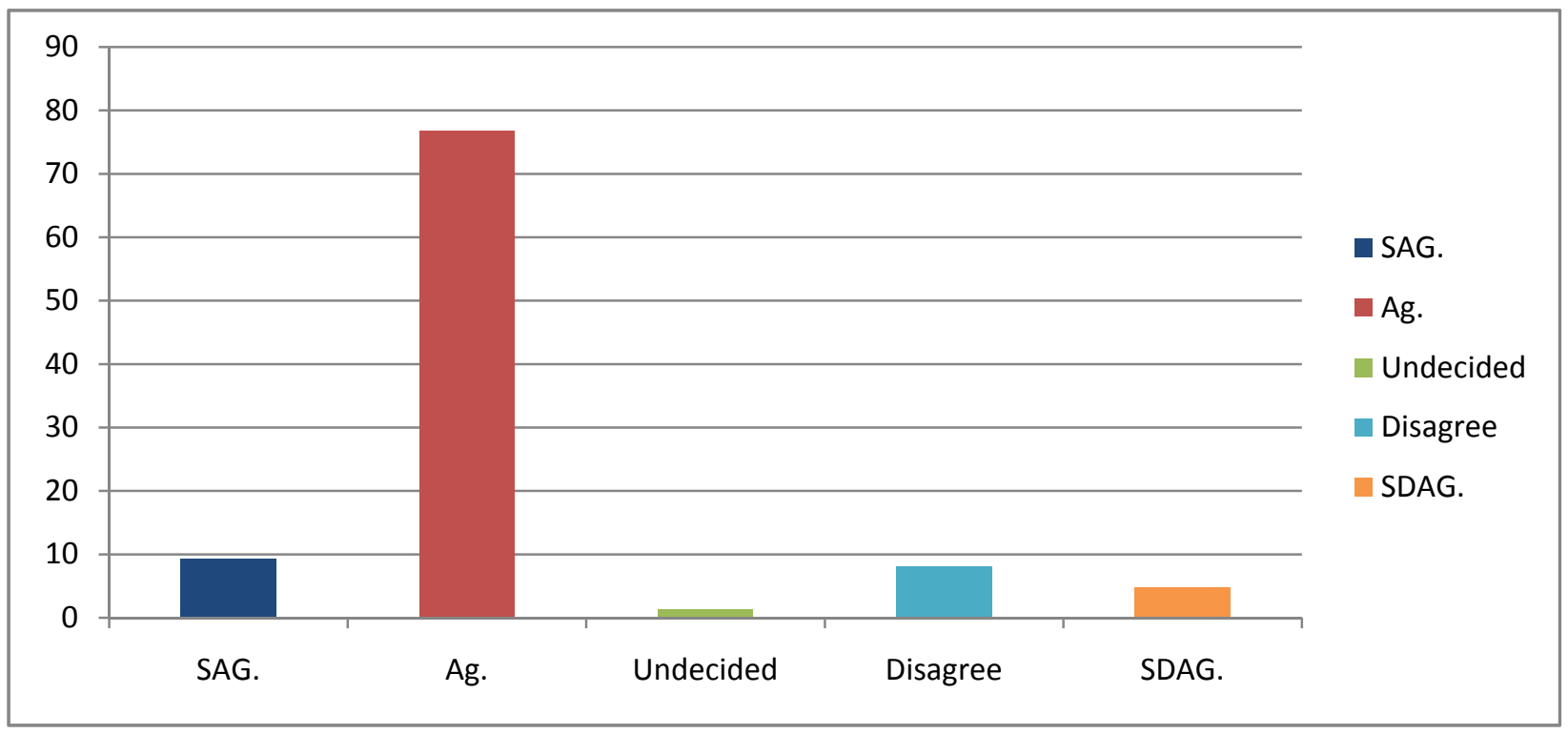

Figure 4. use of L1 in illustrating gramatical rules

In some interactions, certain Arabic words show that there is a discussion about illustrating a certain grammatical rule, which take formulaic forms: Fi fi'el (there is a verb), Ha nata'raf ala (we shall know ..), hina lau lahazna taji ma'ha (as we noticed here it comes with) 'to', mush kida (is it not so?), kiwais (OK), nashuf (let's see), tayib (OK) fi eibarat mua'yana (there are certain expressions), Hina ghal laihum bardu (here also he said).

The following conversation shows how infinitive verb is explained using Arabic words: 
S4: Fi fi'el (there is an infinitive verb) infinitive...

$\mathrm{T}$ : Ha nata'raf ala al (we shall know the) 'infinitive form'. There are two types of infinitive forms $\boldsymbol{m a}$ 'rufa (well known). Infinitive with 'to', biji ma'ahu' to', kiwais (OK).

T: Hina lau lahazna taji ma'ha (as we noticed here it comes with) 'to', as in 'he decided to ...'. Ya'ani al fiel 'decided', yiji ba'dihu al (it means that after the verb 'decided' there comes the infinitive verb with 'to'.

The results from Figure 4 and the conversation are supported with the confession of some teachers, in the interviews, to use L1 in explaining English grammatical rules as in the following:

I used L1 mainly in illustrating the grammatical rules, especially the difficult rules introduced for the first time. It is useful in this field.

I switched to Students' L1 more in grammar .....

I used L1 mostly in the field of grammar as it needs more attention, to be explained and understood.

The deliberate use of L1 in illustrating certain grammatical rules has been confirmed by some studies in bilingualism. Prodromou (2002) found that 27 out of the 100 beginner students agreed that it was useful to explain differences between L1 and L2 grammar. However, intermediate and advanced students did not see much utility in explaining the grammatical differences. Muftah and Rafic-Galea (2013) have found that adult Arab students learning English had difficulty mastering the use of the $3 \mathrm{sg}$-s due to first language (L1) interference. This suggests that there is a need to use L1 in explaining grammar especially by comparing the grammatical systems of the two languages, L1 and L2.

\section{Organizing classrooms}

Figure 5 shows teachers perception about L1 to be used in English classrooms to maintain classroom discipline. 126 (84\%) of the teachers expressed positive attitudes towards using L1 in classroom management. 24 (16\%) of them were undecided, strongly disagreed and disagreed.

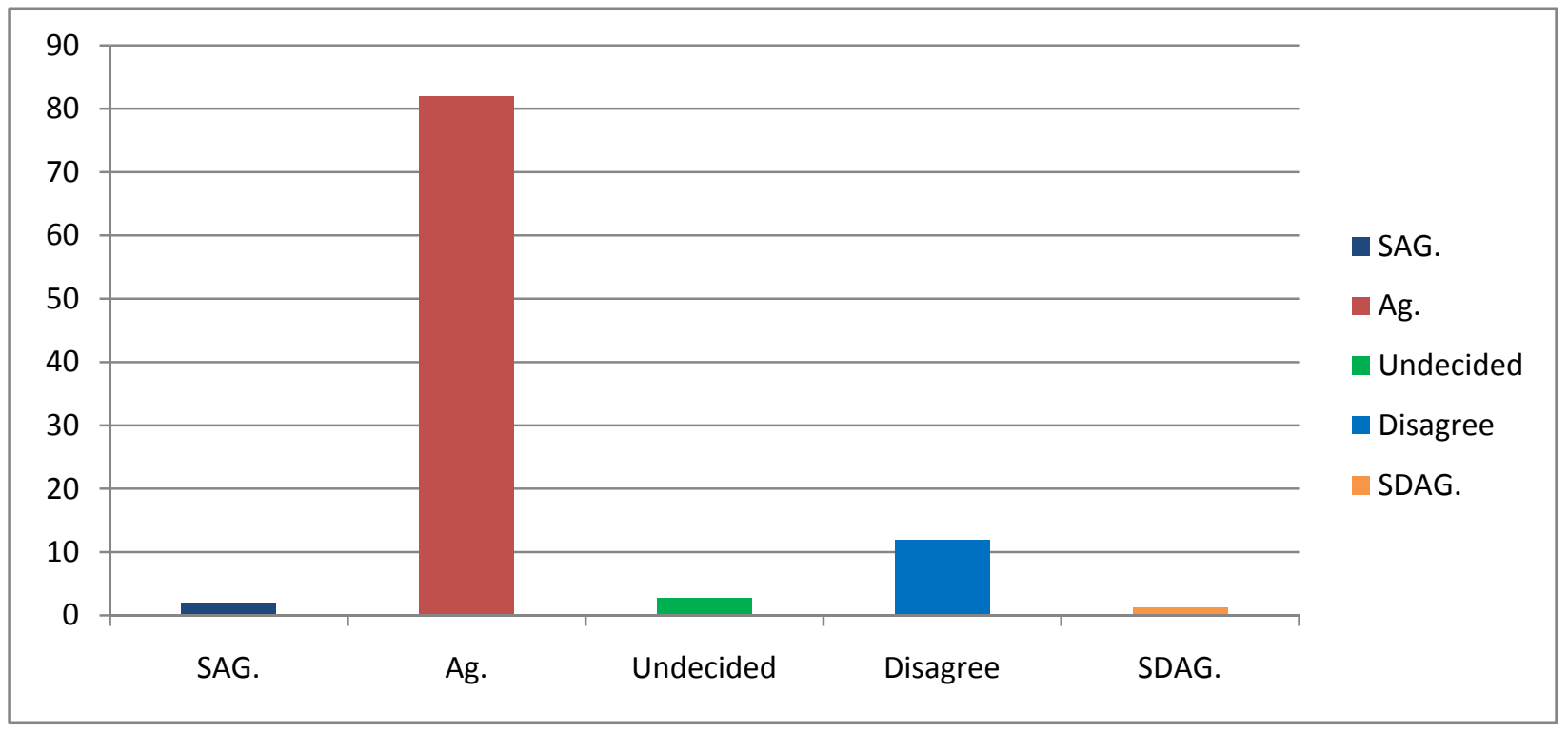

Figure 5. Use of L1 in classroom management

In the following conversations the teacher uses L1 to maintain discipline in an English class:

T: Laih taghaier makan (why do you change your place?).

.a

T: Nasir: yabgha yiharik min hinak? (you want to move from there?

T: Zahrani, focus on the teaching, Mr. Qarni: don’t teach him, don’t teach Mazin Zahrani

b. T: Fi example wala ma fi? (Is there an example or no?). Mumkin eikun fi shakli hiwar (it can be in a form of dialogue). Ayi wahdah eikun eindaha wahda tashrika fi (Any student can have another colleague to share the dialogue). Ayi wahdah eikun eindaha jarata mathalan (any one can have her neighbor, for instance).

many studies in the literature strongly support this tendency, using L1 in organizing an English class. Macaro (1997) argued that some teachers switched to students' L1 after failing to pursue an activity when using L2 only. Macaro 
found that excluding L1 means depriving students of an important vehicle for language learning. Storch and Al Dosari (2010), found that L1 has been helpful in organizing L2 classrooms. More precisely, Franklin (1990 in Jingxia 2010) showed that $68 \%$ of the teachers (in his study) preferred L1 use in their classrooms. Moreover, Jingxia (2010) found that $9.6 \%$ of the use of L1 in the L2 classroom was devoted to managing classes, in order to assure that students would "violate classroom discipline". He reiterated that L2 teachers switched to L1 to criticize and maintain the class discipline.

\section{Praising and encouraging students}

Figure 6 below shows whether those teachers/lecturers use L1 in their English classes to help students feel more comfortable and confident, i.e. raise their morale. A vast majority of the respondents - 133 (88.7\%) strongly agreed or agreed to this statement, while only $17(11.3 \%)$ of them were undecided, disagree, and strongly.

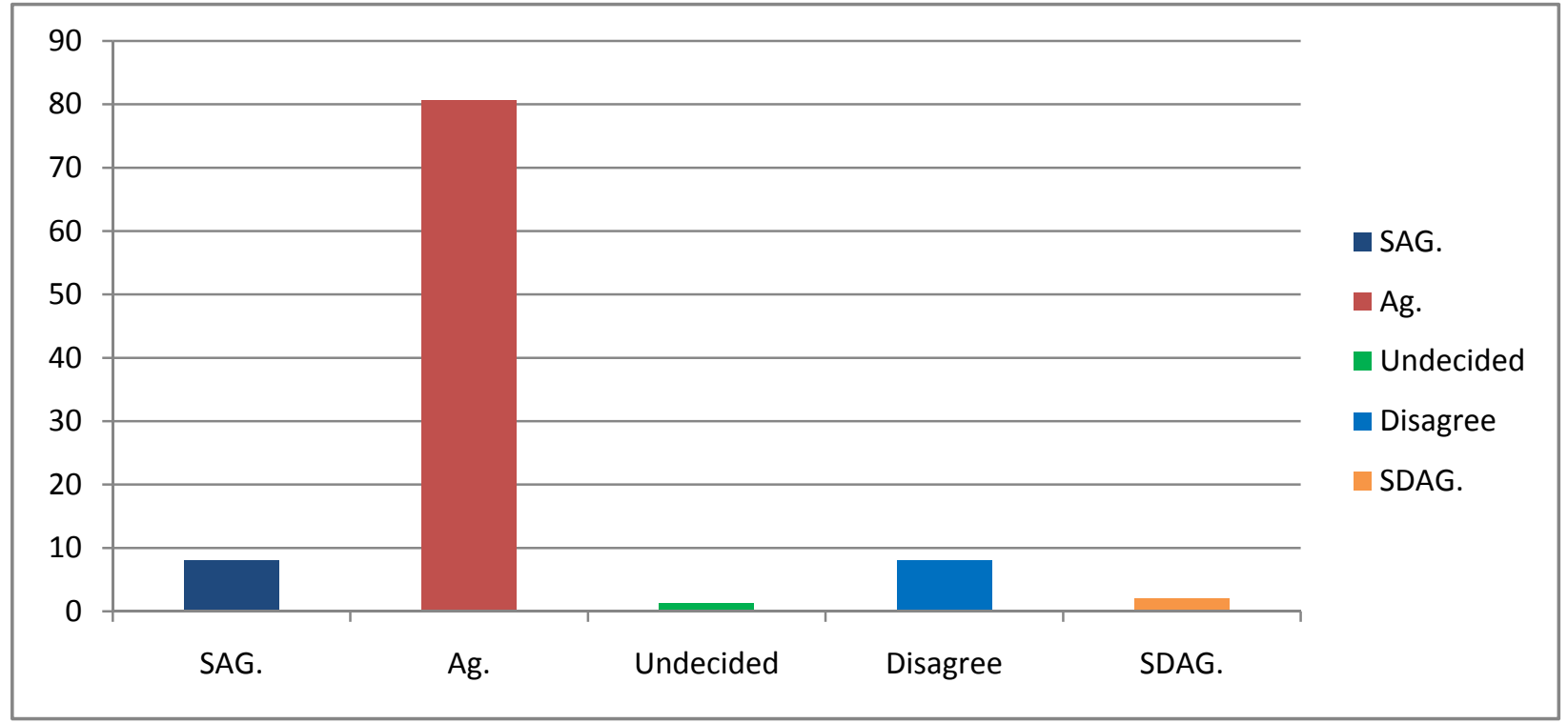

Figure 6. Role of L1 in motivating students to learn L2

From our class observation, it was obvious that teachers used certain Arabic words for praising and encouraging students after successfully completing a task. Words such as: shatir 'clever', ya salam alaiki 'you are good', shukran 'thank you', tamam (that is right) and masha'a allah alaikum 'god bless you'. In the following excerpt, Grade 5 teacher of the basic level used CS at the beginning of the discussion to prepar the students to use English actively in the rest of the discussion. He even encouraged the students when they asked for propper pronunciation of certain words. Consider the following excerpt:

T: Tayib wahid bai hinak ghal ya ustaz 'ture' nantuka 'cha', tawali ha naghoul shinu? (OK, one student there asked me why the 'ture' were pronounced 'cha', we will always say them as 'cha'. Excellent.

$\mathrm{T}$ : Yala daireen nafarain kida shutar ughoulu al kalam da (OK, we need two good students to say the same things). Aha inta minu (OK, you are who: Mohamed Al Amin), tani minu (again who is he?), one girl.

One lecturer also used the Arabic word, 'mabrouk'.(good luck), as a reward for finding the meaning of 'price':

T: Mara tanya (Once aga). Add prices to the items. Ya'ni adeef (meaning add) some prices. Write here and here together.

S11: Price (ghima).

T: Mabrouk (good luck).

The same teacher, in another class, mocked at his students as they were combing in different hair stylest (but not focusing on theclassl):

T: Hello, istishareen (consultants) I know you are very interested in this area (hair cut styles).

T: Good. 
This was further echoed by the confession of the interviewed teachers who saw CS as a strategy to enable students feel more comfortable, especially those with lower proficiency in English:

Week students would feel more comfortable ....

Students feel more comfortable when using L1 (Arabic), when their English is poor and cannot understand the passage and context, especially those students who do not know the meaning of key words.

So, CS makes students' feel comfortable in the class when learning L2. This finding is consistent with research studies in the field of CS (Canagajarah, 1995; Jingxia, 2010; Kang, 2008; Polio and Duff, 1994 in Jingxia,2010; Rose, 2006). For instance, Canajaragah (1995) concluded that CS had been found to be an important teaching strategy in managing the classroom and lowering students' affective filter. Higareda et. al (2009), found that L1 is used to relate to students - that is, to lower their affective filter so that they feel comfortable and at ease in their ESL classrooms. In the same vein, Kang (2008), looking at the best ways to make students comfortable, found that paying attention to students' interest was principal - that is, making them feel comfort and confident by using their L1 in the class. Likewise, Rezavani and Rasekh (2011) have found that teachers at elementary schools in Iran used students' L1 for encouraging students and boosting their confidence, particularly when facing a difficult task.

\section{Conclusions}

Though the frequent use of L1 has been criticized, yet many teachers who participated in this study believe that the use of L1 is unavoidable at both basic and secondary levels in the Sudan, and tertiary level in Saudi Arabia. In classrooms where students and teachers share the same L1, there is a tendency for using it in various aspects and activities. Obviously, it is more natural to use L1 with others who share it for it is easy and more communicatively effective. Above all, using L2 all the time could be a source of embarrassment particularly for shy students and those who feel that they are not very proficient the target language. This suggests that L1 is crucially important in the process of language teaching and learning.

In nutshell, the findings of the present study revealed that teachers had an acceptable belief in the various pedagogical uses of Arabic (L1) to extend interactions of ESL i.e explaining meaning and new vocabulary, guiding interpretation, transmission of lesson content, illustrating grammatical rules, organizing classrooms and praising and encouraging students. CS, then, is a teaching strategy in EFL classrooms for the different functions it serves in teaching a foreign language. Consequently, students' L1 (i.e. Arabic) should not be devalued or underestimated as these classrooms' discourse, would be influenced by the social community outside. It is not possible, however, to isolate classrooms from the societies in which they are situated in.

Therefore, the idea of total prohibition or avoidance of L1 in EFL classrooms was not supported by the teachers and lecturers surveyed by the present study. This might imply that the exclusive use of English in the class could perhaps minimize the effectiveness of students' learning of the language. Consequently, L1 use in EFL classrooms should not be discouraged; rather, it should be allowed to help students in learning a foreign language. As Cook(2001) put is L1 use in ESL classrooms may help improve the current teaching methods and lead to new developments in ESL methodology.

The findings also imply that there is a need to set a new principled approach towards teaching English to speakers of other languages in which students' L1 should have a considerable room. the new approach can provide some remedial measures removing potential obstacles that may occur in process teaching English to speakers of other languages. These measure include suitable teaching materials, tasks and activities.

\section{References}

Abalhassan, K. M \& Alshalawi, H.G. (2000). Code-switching of Arab speakers of English as a second language in the United States. Intercultural Communication Studies X(1), 179-188.

Adendorff, R. (2003). Code switching amongst Zulu-speaking teachers and their pupils: Its functions and implications for teacher education. Language and Education Vol. 7(3),141-162. http://dx.doi.org/10.1080/09500789309541356

Atkinson, D. (1987). The mother tongue in the classroom - a neglected Resource? ELT Journal 41(4), 241-247. http://dx.doi.org/10.1093/elt/41.4.241

Auerbach, E. (1993). Reexamining English in the ESL classroom. TESOL Quarterly, 27(1), 9-32. http://dx.doi.org/10.2307/3586949 
Awad El Karim, A. A. ( 2003). Discourse strategies and dynamic analysis of code-switching as an ongoing meaning-negotiation process. Unpublished $\mathrm{Ph}$. D. Thesis, University of Khartoum, Sudan.

Brown, H. D. (4 $4^{\text {th }}$ edition). (2000). Principles of language learning and teaching. Englewood cliffs NJ: Prentice Hall Reagents.

Buckmaster, R. (2002). Using L1: what kind of sin? Retrieved from http://iatefl.org.pl/ nletter18/nlet18-2. Html.

Burden, P. (2001). When do native English speaking teachers and Japanese college students disagree about the use of Japanese in the English conversation classroom? Retrieved from http://langue.hyper.ac.jp/pub/ttt/01/apr/burden.

Burenhult, N. \& Flyman-Mattson, A. (1999). Code-switching in second language teaching of French. Lund University; Department of Linguistics (S-I working papers), 47, 59-72.

Canagarajah, A. S. (1995). Function of Code-switching in ESL Classrooms: Socializing Bilingualism in Jaffna. Journal of Multilingual and Multicultural Development. Vol. 16 (3), 137-195. http://dx.doi.org/10.1080/01434632.1995.9994599

Chaudron, C. (1988). Teacher talk in second classrooms. In C. Chaudron (ed.). Second Language classrooms, 50-89. Cambridge: Cambridge University Press.

Cook, V. (2001). Using the First Language in the Classroom. The Canadian Modern Language Review, 57(3), 403-414. http://dx.doi.org/10.3138/cmlr.57.3.402

(2002). Portraits of the L2 User. Clevedon: Multilingual Matters.

Cole, S. (1998). The use of L1 in Communicative English Classrooms. The Language Teacher, 22, 11-13.

Cunningham, C. (2000). Translation in the classroom: A useful tool for second language acquisition. Retrieved from http://www.cels.bham.ac.uk/resources/essays/cindyc2.pdf

Dajani, D. (2002). Using the mother tongue to become a better student. Modern English teacher, Vol. 11(2), 65-67.

Damien, T, Philippe, S. and Nikos, N. (2008). The effects of an experimental programme to support students' autonomy on the overt behaviours of physical education teachers. European Journal of Psychology of Education. Vol.3, 239-253.

Deller, S. (2003). The language of the student. English Teaching Professionals, 26.

Ellis, R. (1985). The role of the first language. Annual Review of Applied Linguistics, 19, 3-21. Oxford: Oxford University Press.

. (2000). Teaching from experience: A new perspective on the non-native teacher in adult ESL. Australian Review of Applied Linguistics, 25 (1),70-107.

Fasold, R. (1984). The Sociolinguistics of Society. Blackwell: UK and Cambridge, USA.

Ferrer, V. (2005). The mother tongue in the classroom: cross-linguistic comparison, noticing and explicit knowledge. Retrieved from www.teachenglishworldwide.com/articles/Ferre.

Frankenberg-Garcia, A. (2000). Using Portuguese in the Teaching of English. Retrieved from http://www.Portuguese mct.pt/ Repositorio /Frankenburg- Garcia 2000b.doc.

Gabrielatos, C. (2001). Shopping at the ELT supermarket: Principled decisions and practices. ELT News 144. ERIC, ED478747

Harbord, J. (1992). The use of the mother tongue in the classroom. ELT Journal, Vol. 46(4), 350-355. http://dx.doi.org/10.1093/elt/46.4.350

Harmer, J. (2001). The Practice of English Language Teaching. Edinburg Gate: Pearson Education Ltd.

Hazaymeh, O. (2004). The Impact of Bilingualism on ELT in Jordan. South Asian Language Review, Vol. XIV,( 2004, January-June, Nos.1 \& 2. Al-Balqa' Applied University, Jordan. Available from http://www.salr.net/Documents/Omar.pd.

Higareda. S, López, G. \& Mugford, G. (2009). Interpersonal and Transactional Uses of L1 in the Foreign-Language Classroom. PROFILE Issues in Teachers' professional Development, Vol. 11(2), 43-54.

Hidayati, I. S. (2012). Evaluating the role of L1 in teaching receptive skills and grammar in EFL classes. Indonesian Journal of Applied Linguistics, Vol. 1(2),17-32. 
Hosoda, Y. (2000). Teacher codeswitching in the EFL classroom. JALT Journal, 22, 69-93.

Kang, D. (2008). The Classroom Language Use of a Korean Elementary School EFL Teacher: Another Look at TETE. System, 36, 214-226. http://dx.doi.org/10.1016/j.system.2007.10.005

Krashen, S. (1985). The Input Hypothesis: Issues and Implications. New York: Longman.

Janulevicine, V. \& Kavlaliauskiene, G. (2002). Promoting the fifth skill in teaching ESP. Retrieved from www.esp-world-info/Articles.

Jingxia, L. (2010). How Much the First Language is there in Teacher's talk in EFL classrooms? The Open Applied Linguistics Journal, 1:59-67. http://dx.doi.org/10.2174/1874913500801010059

Langer, R. (2001). The effect of home language use in the ESL classroom: additive or subtraction. Retrieved from: the effect of home language in the ESL classroom. 5-langer.htm.

Larsen-Freeman, D. ( $2^{\text {nd }}$ edition). (2000). Techniques and principles in second language teaching. Oxford: Oxford University Press.

Linder, D. (2002). Translation. English teaching professional, 23, 39-41.

Lynch, T. (1996). Communication in the Language Classroom. Oxford: Oxford University Press.

Macaro, E. (1997). Target Language, Collaborative Learning and Autonomy. Clevedon: Modern Language in Practice: Multilingual Matters Ltd.

Mattsson, A. \& Burenhult-Mattsson, N. (1999). Code-switching in second language teaching of French. Working Papers 47, 59-72.

Muftah, M. \& Rafic-Galea, S. (2013). Error Analysis of Present Simple Tense in the Interlanguage of Adult Arab English Language Learners. English Language Teaching, 6 (2), 146-154. http://dx.doi.org/10.5539/elt.v6n2p146

Muir, K. (2001). Code-switching in EFL teacher discourse. Unpublished Master of Applied Linguistics thesis: Macquarie University, Sydney, Australia.

Nadeem, M. (2012). Urlish: A Code Switching/Code mixing Pedagogical Approach in teacher Education. Journal of Research Reflections in Education, Vol.6 (2),163-172.

Pica, T. (1992). The textual outcomes of native speaker-non-native speaker negotiation: "what do they reveal about second language? In Kramsck, C. and sally mc Connell Ginet (eds.). Texts and context. Cross-dictionary perspectives on language study. New York: D.C. Heath and Company.

- (2000). Tradition and transition in English language teaching methodology. System, 28,1-18. http://dx.doi.org/10.1016/S0346-251X(99)00057-3

Prodromou, L. (2001). From mother tongue to other tongue. Pridges 5. Retrieved from http://www..Toesolgreece.com/.

Rezavani, E. \& Rasekh, A. E. (2011). Code-switching in Iranian Elementary EFL Classrooms: an Exploratory Investigation. English Language Teaching, Vol. 4(1),18-25.

Richards, J.C. \& Rogers, T.S. (1986). Approaches and Messages in Language Teaching. Cambridge: Cambridge University Press.

Rinnvolucri, M. (2001). Mother tongue in the foreign language classroom: why and how. Modern Language Teacher, $10(2), 41-44$.

Rose, S.(2006). The functions of code switching in a multicultural and multilingual high school. An Unpublished M.Phil in Intercultural communication, Stellenbosch University, South Africa.

Schweers, C.W. (1999). Using L1 in the L2 Classroom. English Teaching Forum, 37(2),6-13.

Swain, M. \& Lapkin, S. (2000). Task-based second language learning: The uses of the first language. Language Teaching Research 4, 253-276.

Seliger, H. W. and Shohamy, R. (1989). Second language research methods. Oxford: Oxford University Press.

Sipra, M. A. (2007). Bilingualism as teaching aid in a language class: L1 as a facilitator in teaching/learning process of L2 at intermediate/certificate level. An unpublished Ph.D. National University of Modern Languages, Islamabad, Pakistan. Retrieved from: http://prr.hec.gov.p./thesis/2635.pdf. 
Skiba, R. (1997). Code Switching as a Countenance of Language Interference. The Internet TESL Journal, 3 (10). Retrieved from tp://iteslj.org/Articles/Skiba-CodeSwitching.html.

Skutnabb-Kangas, T. (1994). Mother Tongue Maintenance: the Debate: Linguistic Human Rights and Minority Education. TESOL Quarterly, 28 (3),24-628. http://dx.doi.org/10.2307/3587314

Stern, H.H. (1992). Issues and options in language teaching. Oxford: oxford university Press.

Storch, N. \& Al Dosari, A. (2010). Learners' use of first language (Arabic) on pair work in an EFL class. Language Teaching Research, Vol. 14 (4), 355-375. http://dx.doi.org/10.1177/1362168810375362

Swan, M. (1985). A Critical Look at the Communicative Approach. ELT Journal, 39(2):76-87. http://dx.doi.org/10.1093/elt/39.2.76

Swain, M. \& Lapkin, S. (2000). Task-based second language learning: The uses of the first language. Language Teaching Research 4, 253-276.

Ur, P. (1996). A Course in Language Teaching. Cambridge: Cambridge University Press

Ustunel, E. \& Seedhouse, P. (2005). Why that, in that language, right now? Code-switching and pedagogical focus. International Journal of applied Linguistics, http://dx.doi.org/10.1111/j.1473-4192.2005.00093.x

Weschler, R. (1997). Uses of Japanese (L1) in English classroom: Introducing the Functional-translation Method. Internet TESOL Journal 3(2). Retrieved from http://www.aitec.ac.jp/iteslj.

\section{The questionnaire}

\section{Appendix A}

Could you please complete the following questionnaire and return it at your earliest convenience. Please note that this information is strictly confidential.

1. You use Arabic to help explaining and providing the meanings of new words and items

a. Strongly agree $b$. agree c. undecided d. disagree e. strongly disagree

2. Arabic aids the comprehension of English different topics taught in a better way.

a. Strongly agree $b$. agree c. undecided d. disagree e. strongly disagree

3. In your English classes, you translate words, phrases, sentences and even texts to ensure understanding lesson content.

4. You use Arabic to illustrate and explain complex grammatical points and rules.

a. Strongly agree $b$. agree c. undecided d. disagree e. strongly disagree

5. You use to maintain classroom discipline and organize classes.

a. Strongly agree b. agree c. undecided d. disagree e. strongly disagree

6. Arabic is used in ESL classrooms to help students feel more comfortable and confident.

a. Strongly agree b. agree c. undecided d. disagree e. strongly disagree

\section{The semi-structured interview}

\section{Appendix B}

The aim of the semi-structured interview is to verify your attitudes from your experience as ESL teacher, towards your students' L1: is this use helpful in increasing the interaction between them and you as a teacher and the text and hence reinforce their ESL competence at large. This semi-structured interview has been designed for basic, secondary and college teachers of English. Further, your answers will confidentially be used for research purpose only.

1. In which fields do you switch to students' L1 (Arabic) more: grammar, vocabulary, comprehension of passages, content of the lesson or to organize the classrooms?

2. Do you think that using students' L1 helps comprehending the lesson content in ESL?

3. Is switching to Arabic in your ESL classroom, a helpful tool to increase your classroom interaction with your students? Please elaborate.

4. Do you think that using English only in ESL classrooms helps students learn the subject matter better and interact fluently? Please analyze with examples.

5. Do you think that switching to students' L1 (Arabic) frequently will facilitate ESL fluency on the part of your students? Please support your answers with examples.

6. Do you think that your ESL students feel more comfortable when switching to their L1 (Arabic)? Please specify. 